IRA-International Journal of Management \& Social Sciences

ISSN 2455-2267; Vol.04, Issue 03 (2016)

Pg. no. 568-578

Institute of Research Advances

http://research-advances.org/index.php/RAJMSS

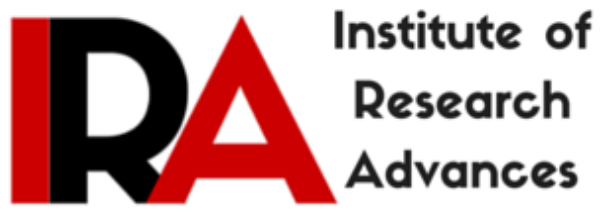

\title{
A Content Analysis of Emotional and Rational Appeals in Selected Products Advertising
}

\author{
Dr. Priyaka Khanna \\ Department of Commerce \\ Khalsa College for Women, Ghumar Mandi \\ Civil Lines, Ludhiana-141001, Punjab, India.
}

Type of Review: Peer Reviewed.

DOI: http://dx.doi.org/10.21013/jmss.v4.n3.p7

\section{How to cite this paper:}

Khanna, P. (2016). A Content Analysis of Emotional and Rational Appeals in Selected Products Advertising. IRA-International Journal of Management \& Social Sciences (ISSN 2455-2267), 4(3), 568-578. doi:http://dx.doi.org/10.21013/jmss.v4.n3.p7

(C) Institute of Research Advances

\section{(cc) EY-NO}

This work is licensed under a Creative Commons Attribution-Non Commercial 4.0 International License subject to proper citation to the publication source of the work.

Disclaimer: The scholarly papers as reviewed and published by the Institute of Research Advances (IRA) are the views and opinions of their respective authors and are not the views or opinions of the IRA. The IRA disclaims of any harm or loss caused due to the published content to any party. 


\section{ABSTRACT}

A content analysis of 200 television commercials was conducted in order to identify the frequency of emotional and rational appeals under important product categories. The study also investigated the most preferred appeals by rural and urban children of Punjab.480 respondents in the age group 8-14 years were selected for the study. Age and gender differences with respect to preferences in regard to appeals were also analyzed. The study indicated that all number of appeals present in food and beverages were large and the least were present in the case of toys and games. Emotional appeals like fun and happiness, jingles and slogans, humor was present in every commercial forming the base of appeals in commercials. The most typical appeals in commercials aimed at male children were action-adventure, sports, and play, whereas commercials aimed at female children emphasized nurturing, physical attractiveness, friendship, and romance. Having the best, competition, and achievement were the dominant appeals in commercials aimed at male teenagers, whereas romance, sexuality, and belonging to a group were emphasized in commercials aimed at female teenager.

Keywords: Television advertising, Content analysis, Gender-differences, Emotional and rational appeals.

\section{Introduction}

Advertising is a promotional activity for marketing goods and services. The study of content analysis of children's television advertising has become very interesting area in academic research. The whole idea about the content analysis revolved around understanding the commercial processes involved while children view advertising. This also considers the manner in which children perceive and react to these advertisements. A relatively small number of studies have concentrated on the content of advertising aimed at children. The content analysis of advertising can provide a rich data source about the underlying assumptions of advertisers concerned with which advertising characteristics will attract specific audience groups. It is a valuable tool for predicting the effectiveness of advertising. One important antecendent of the effectiveness of a persuasive message is the enjoyment triggered by its content. It is an important instrument to improve our understanding of advertising effectiveness. Previous content analysis studies had focus primarily on what is being advertised but scholar in recent studies had attempted to examine what is being said to children and how it is being said (Palan and Lacznicak, $1988)^{1}$.

An appeal can be described as the persuasive selected by the advertiser to make the product attractive to the customer. It is the specific way in which a commercial relates to certain tastes and preferences of customer. It is connection between the emotions or logic of the advertisement and the consumer's response to the advertisement (Wells, Moriarty and Burnett, 2006) ${ }^{2}$. Both brand attitude and purchase intention are largely determined by the consumers' attitudes towards the commercials. When children like the commercial, the chance that they also like the brand and ask their parents to buy the brand is greatly enhanced (Derbaix and Bree, $1997^{3}$ : Moore and lutz, 2000 ${ }^{4}$ ). It is evident, therefore that the use of appeals that suit the tastes and preference of children and teenagers can contribute greatly to advertising effectiveness. In general message appeals can be categorized into two overarching categories; Rational and Emotional.

A rational appeal follows the hierarchy of effects stages of awareness, knowledge, liking, preference, conviction, and purchase. An advertising with a rational appeals leads to a stronger conviction about a product's benefits, so that the purchase is eventually made. They are generated in traditional models of information processing where consumers are expected to make purchase decisions based on an individual's sense of logic and reasoning. The purpose of a rational appeal is to emphasize the characteristic features, and benefits of the product to demonstrate the value of owing or using that particular brand. Such appeals may include detailed information about a product such as specific features, durability and value. Successful rational appeals rely on their persuasive power of arguments or 
reasoning. Examples of rational appeals include price, quality, performance, reason why, and comparative advertising.

Emotional appeals are directed primarily at an individual's psychological, social or symbolic needs. Emotional appeals touch on a variety of feelings including fear, humor, love, anxiety and sex. Most creatives view emotional advertising as the key to developing brand loyalty. Creatives want customers to feel a bond with the brand. Emotional appeals reach the more creative right side of the brain. Visual cues in ads are important in emotional appeals. To potentially enhance their persuasive effects; an advertisement can actually include more than one type of emotional appeal. Since they are designed to persuade by manipulating one's feelings, emotional appeals often come under security.

To date four earlier studies using content analysis have investigated the use of appeals in advertising aimed at children (Barcus, 19805; Kunkel and Gantz, 19926; Winick et al.,19737) These studies concentrated on commercials aimed at children upto the age of 12. In these studies, four appeals often prevailed, namely happiness, fun, taste and product performance. Other prominent appeals were action, adventure, sports, humor, peer-popularity, feeling of power, and feeling of being grown up.

\section{Literature Review}

Moniek Buijzen and Patti M. Valkenburg $(2002)^{8}$ examined the content Analysis of 601 commercials in order to identify the appeals that characterize commercials aimed at children and teenagers. Each appeal was coded as being present or absent in the commercial. The commercials were distinguished on the basis of commercials "typically aimed at children" or "typically aimed at teenagers" and aimed at a general audience. The result showed that the most typical appeals in commercials aimed at male children were action-adventures, sports and play, whereas commercials aimed at female children emphasized nurturing, physical attractiveness, friendship and romance. It was found that certain products are more often advertised to specific age groups as more than $70 \%$ of commercials aimed at children are commercials for toys and candy. It is through these commercials for toys and candy that children are confronted with specific child-related appeals, such as play, fun, action-adventure and humor.

Neeley and Schumann (2004) ${ }^{9}$ extended previous studies examining spokes-character influence on children and examined the effects of character, action and voice. Two experimental studies i.e. 22 second two-dimensional animated nock commercials illustrating a character paired with a product were created for each study. All participants were two to five year old (study 1 mean age $=46$ months, study 2 mean age $=43$ months). The results revealed that advertisements containing an animated spokes-character generate high levels of attention, character recognition and liking, and product recognition and liking. Researchers found that due to inconsistent behaviour of children they only named and responded to lost toy they played with or food they ate. The main limitation of the study was that the researchers assumed that the presence of spokes-character is beneficial to the development of product

David Allan (2006) ${ }^{10}$ examined the effect of popular music in advertising to determine the effect of both theoretical and practical implication of music on the processing of advertising messages. Fifty two percent of the subjects were female and 48 percent were male. Fifty-eight percent of the subjects were white, 27 percent were African American, 6 percent were Ascan, and 7 percent defined themselves as others, all the participants were randomly assigned to hear one of the four tapes. It also has ability to enhance memory for the brand. However effects of significant songs and artists on the brand memory were observed for one of the brands (Long) and the artist (Eminent) sensitive to the level of personal significance they have for advertising message integrated in popular music than females.

Robert and Pettigrew (2006) ${ }^{11}$ conducted in- depth interviews with 22 mothers of primary school children, all mothers reported that premiums led to pestering and begging for product purchases. Mothers thought that premiums involving collectables were particularly influential in driving demand for food products such as sweet cereals, chips and fast food. Mothers also noted that their children associate 'fun' with 
premiums (such as the trading of Tazos or cards) and, subsequently, the brand. However, fun was also associated with products themselves, as distinct from the premium (participants said that their children play with fun foods' by dunking (Dunkaroos), unwinding (Roll-ups) and shredding (Cheese Stringers).

Page M.R. and Brewster A. (2007) $)^{12}$ examined the extent to which promotional strategies and attention elements appear in a sample of children" food commercials. 147 distinct food commercials were selected as samples. 20 separate promotional strategies and 20 different attention elements were analysed. The findings showed that the most frequently used promotional strategies were the use of jingles/ slogans, showing children the food, and the use of product identification characters. The use of animation, real children, animals with human characteristics, fast cutting scenes, exciting fast-paced music, humor and color effects were the most used attention elements in the commercials.

Ganapatthy V. (2009) ${ }^{13}$ in his article explains that 'humor' is a strong weapon for many brands to draw the customers' attention. To beat the clutter and break the ice, companies are increasingly using humor in their ads as it forces the audience to watch, laugh, enjoy and most importantly help the audience to recall the brand. Humorous ads have better and easy recall because they elevate the consumers' happiness and moods. Humor can be deployed in various ways, which include, using a comedian; capitalizing on the current Topics; strong Idea-based humor, which requires low investments and which low high in emphases purchases and those ads which have to explain the benefits of the products to customers more clearly. Now many advertisers are using comedian to introduce humor in ads as leading Brand Dominos Pizza has recently taken the services of Paresh Rawal to be successful.

Steve Dix et al (2010) ${ }^{14}$ investigated in their paper how sports celebrities can be perceived as role models and influence young adult consumers' purchase and behaviour and intention and also to examine whether this influence differs between males and females. A convenience sample was drawn from students in university in Western Australia. The results revealed that attitude role model endorsers have a positive influence on young adults' product switching behaviour, complaint behaviour, positive word of mouth behaviour and brand loyalty. This confirms the assumption that sports celebrities are important socialization agents and can have significant impact on purchase behaviours and intention of young consumers.

Boyland J. Emma et al (2011) ${ }^{15}$ conducted a study to quantify the natures and extent of use of persuasive marketing techniques in television advertising to promote foods to children. Twenty promotional appeals were selected for final coding, out of which 7 interpreted as rational \& rest emotional, being more in number, emotional appeals were justified on the ground of four studies made in past covering which stated that emotional appeals dominates in commercials aimed at children. The objective of the study is to analyse the frequency of emotional and rational appeals present in commercials for different product categories and to investigate the extent of importance given to these appeals by rural and urban children of Punjab. Gender and age-wise differences were identified.

To date four earlier studies using content analysis have investigated the use of appeals in advertising aimed at children. In these earlier studies four appeals often prevailed, namely happiness, fun, taste, and product performance. The present study is the extension of earlier studies and have investigated 25 emotional and rational appeals. 
Table 1: List of rational and emotional appeals selected for the study

\begin{tabular}{|c|l|c|ll|}
\hline $\begin{array}{c}\text { S. } \\
\text { No. }\end{array}$ & Rational Appeals & S. No. & Emotional Appeals & \\
\hline 1. & Product Feature Appeals & 1. & Fun/ Happiness & \\
\hline 2. & Economy \& Savings & 2. & Humor & \\
\hline 3. & Newness & 3. & Jingles/Slogans & \\
\hline 4. & Contest /Premium or product tie in & 4. & $\begin{array}{l}\text { Presence of Children \& Peer } \\
\text { Acceptance }\end{array}$ \\
\hline 5. & Taste/ Flavour or Smell & 5. & Scenic Beauty & \\
\hline 6. & Safety Appeals & 6. & $\begin{array}{l}\text { Social status, like presence of } \\
\text { celebrities }\end{array}$ \\
\hline 7. & Health/ Nutrition & 7. & Fear Appeals & \\
\hline 8. & Financial security & 8. & Sport or Physical Performance & \\
\hline 9. & Health & 9. & Action and Adventure & \\
\hline 10. & Having the best & 10. & Musical Appeals \\
\hline 11. & Having natural,organic ,food and & 11. & Physical attractiveness/ beauty \\
\hline 12. & Energy & 12. & Parental pleasing \\
\cline { 2 - 5 } & & 13. & Sex appeals \\
\hline
\end{tabular}

Secondly the study also investigated the preference given to appeals both by rural and urban children. Unlike earlier studies we investigated the gender differences were also analyzed.

\section{Research Objectives}

- To analyze the appeals in different product categories.

- To investigate the preference for promotional appeals by rural and children.

- To observe the gender difference for likeability of promotional appeals.

- To examine the age differences with respect to promotional appeals present in television advertisements.

\section{Research Methodology}

To assess the various promotional appeals present in television commercials aimed at children, television commercials were recorded with the help of Airtel Box for composite two week in the month of Jan.-Feb., 2015 between 08:00 am to 10:00 am on Sunday and between 07:30 pm to 08:30 pm on weekdays. All programs telecasted on following channels mainly relating to children channels were recorded. Recording was done on every alternative day on different channel. In all almost 60 hour programs were recorded. Then all commercials that were telecasted on recorded channels were collected separated. In all a set of 250 to 300 commercials were collected.

After eliminating repetitive commercial finally a sampling unit of 150 commercials was selected, representing 45 ads relating to food and beverages, 35 ads to personal hygiene product, 10 ads to stationery items, 10 ads to electronic gadgets, 20 ads to beauty product and 30 ads to chocolates and candy's, to evaluate the various promotional appeals present in television advertisements. The product categories selected for the study were on the basis of their growth in India. As many as 150 commercials were identified for the above mentioned product categories. Maximum commercials telecasting on these recorded channels related to food and beverages, chocolates and Candies and beauty and grooming 
products. These product categories accounted for 60-70 percent of total commercials telecasted on these channels.

A detailed literature was conducted to identify the emotional and rational appeals used in advertising of selected products. Separate coding sheet was used by both the coders and each appeal was coded as being present (1) or absent (0). Coding was done over a period of one month by the researcher himself and along with a MBA student. Throughout the coding period, the functioning of the codebook and doubtful cases were regularly discussed. Each coder analyzed approximately 45 percent of the sample, 10 percent of the sample was analyzed by both coders in order to determine inter-coder reliabilities. Inter-coder agreement was perfect on the vast majority ( 88 percent) of the appeals that were identified in the study. For majority of the appeals the stronge positive reliability was found (Kappa coefficient $=>0.71$ ). For two appeals (Safety Appeals, parental pleasing), the reliability was lower these two appeals $(.63<$ Kappa $<.65)$. These two appeals were re-evaluated until consensus between the coders was reached.

In order to assess effectiveness of different promotional appeals among children, the importance of these appeals was assessed among children on five point likert scales ranging from "Not at all important" to "Very important". Further few promotional appeals were selected depending on their dominance in different commercials specially targeting children like food and beverages, candy and chocolates, personal hygiene products and toys and games. Comparative analysis of these appeals was made among urban and rural children to assess the extent of importance given to these appeals by them. Gender and age-wise differences were also computed. As the study involves comparisons of rural and urban children in Punjab, so three districts were selected on the basis of population. The district finally selected were Ludhiana from High Population, Moga from Medium Population and Barnala from Low Population. Two villages were selected from each block to cover the rural population. In all 480 children were selected for the study.

Table 2: Age wise and gender wise description of respondents

\begin{tabular}{|c|c|c|c|c|c|c|c|}
\hline \multirow{3}{*}{$\begin{array}{l}\text { Age Group } \\
\text { Urban } \\
\text { Respondents } \\
\text { Ludhiana } \\
\text { Moga } \\
\text { Barnala } \\
\end{array}$} & \multicolumn{2}{|c|}{ 8-10 yrs } & \multicolumn{2}{|c|}{ 10-12 yrs } & \multicolumn{2}{|c|}{ 12-14 yrs } & \multirow{2}{*}{ Total } \\
\hline & Male & Female & Male & Female & Male & Female & \\
\hline & 40 & 40 & 40 & 40 & 40 & 40 & 240 \\
\hline $\begin{array}{l}\text { Rural } \\
\text { Respondents } \\
\text { Sidhwan Bet } \\
\text { Nihal Singh Wala } \\
\text { Barnala Block }\end{array}$ & 40 & 40 & 40 & 40 & 40 & 40 & 240 \\
\hline Grand Total & 80 & 80 & 80 & 80 & 80 & 80 & 480 \\
\hline
\end{tabular}

\section{Results and Discussions}

\subsection{Presence of appeals in television commercials}

Table 3 shows how specific appeals differ for the most important product categories. The results indicated that most of the appeals are generic in the sense that they are used in all the product categories. For example humor, fun, newness and celebrity endorsements prevails in every product category selected. The number of appeals present in food \& beverages were large and least was the case with toys and games. Emotional appeals like, fun and happiness, jingles and slogans, humor was present in almost every ad forming the base of appeals in commercials. However, content was more in case of food and beverages for fun/ happiness (78.22 percent) and in stationery items for humor (91.82 percent) and jingles (83.33 
percent). Least was the content of premium/ contest and parental pleasing in commercials studied. The content of Health appeals in food and beverages was very less (5.56 percent).

Table 3: Prevailing appeals in commercials for the most frequently advertised product.

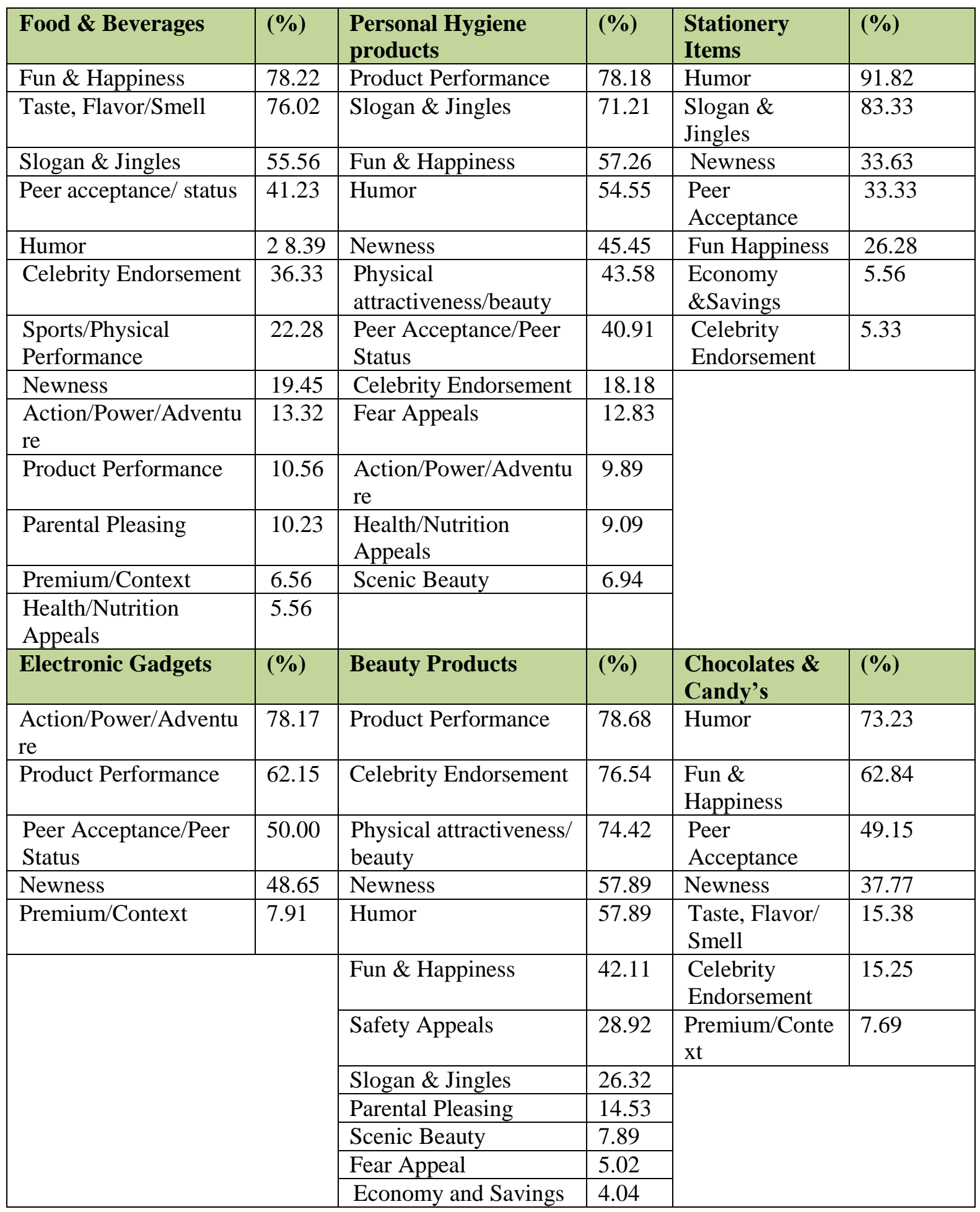

**Computed from primary data 
Celebrity endorsement was more in case of beauty products (76.54 percent) Newness was more in case of beauty products ( 57.89 percent), fear appeals were more prominent in personal hygiene ads like mouthwash, dandruff shampoo, deodorants and beauty products like belching cream, hair remover etc.

\subsection{Comparison of appeals preferred by children of both domicile}

Based on the frequency of the appeals, few dominating emotional and rational appeals were selected and preferences given to these appeals by rural and urban children were analyzed.

Table 4 showed that fun and happiness was the most liked appeal reported by rural children with a mean score of 4.43 followed by economy and saving (4.30), music appeals (4.26), scenric beauty (4.00), humor (4.00), action adventure (3.94), jingles and slogans (3.88) and celebrity endorsement (3.83). The mean score of these appeals indicated that these appeals were considered important and liked by rural respondents. Least importance was given to premium tie in and product performance (3.55). The mean score indicated the rural children have shown higher importance for emotional appeals as compared to rational appeals. Only one rational appeals i.e. economy and saving was considered important by them.

Table 4: Comparisons of preferences for appeals by children

\begin{tabular}{|c|c|c|c|c|c|}
\hline \multirow{2}{*}{$\begin{array}{l}\text { Sr. } \\
\text { No. }\end{array}$} & \multirow{2}{*}{ Promotional Appeal } & Rural & Urban & \multirow{2}{*}{ t-value } & \multirow{2}{*}{ p-value } \\
\hline & & Mean \pm SD & Mean \pm SD & & \\
\hline 1. & $\begin{array}{l}\text { Emotional appeal depicting social } \\
\text { status like presence of celebrity in the } \\
\text { ads. }\end{array}$ & $3.83 \pm 1.39$ & $3.45 \pm 1.37$ & 3.02 & $0.009^{* *}$ \\
\hline 2. & $\begin{array}{l}\text { Emotional appeal like good music for } \\
\text { creation of mood and emotions. }\end{array}$ & $4.26 \pm 1.21$ & $3.87 \pm 1.30$ & 3.40 & $0.008^{* *}$ \\
\hline 3. & $\begin{array}{l}\text { Emotional appeal using catchy } \\
\text { phrases and words in form of jingles } \\
\text { and slogans. }\end{array}$ & $3.88 \pm 1.14$ & $3.73 \pm 1.27$ & 1.36 & $0.121^{\mathrm{NS}}$ \\
\hline 4. & $\begin{array}{l}\text { Emotional appeal depicting use of } \\
\text { adventure/action and thrilling scene. }\end{array}$ & $3.94 \pm 1.40$ & $3.49 \pm 1.31$ & 3.64 & $0.007^{* *}$ \\
\hline 5. & $\begin{array}{l}\text { Rational appeal using } \\
\text { context/premium tie in ads. }\end{array}$ & $3.55 \pm 1.30$ & $3.63 \pm 1.36$ & 0.66 & $0.250^{\mathrm{NS}}$ \\
\hline 6. & $\begin{array}{l}\text { Rational appeal demonstrating } \\
\text { product use, benefits and products } \\
\text { features. }\end{array}$ & $3.55 \pm 1.36$ & $3.43 \pm 1.31$ & 0.98 & $0.168^{\mathrm{NS}}$ \\
\hline 7. & $\begin{array}{l}\text { Rational appeal depicting taste, health } \\
\text { and nutrients claims in the product. }\end{array}$ & $3.61 \pm 1.43$ & $4.00 \pm 1.32$ & 3.11 & $0.008^{* *}$ \\
\hline 8. & $\begin{array}{l}\text { Emotional appeal demonstrating fun } \\
\text { and happiness to induce smiles and } \\
\text { laughter in the ads. }\end{array}$ & $4.43 \pm 1.15$ & $4.28 \pm 1.18$ & 1.41 & $0.117^{\mathrm{NS}}$ \\
\hline 9. & $\begin{array}{l}\text { Emotional appeal demonstrating } \\
\text { presence of striking scenes of nature } \\
\text { scenes, (Mountains, flowing streams } \\
\text { etc.). }\end{array}$ & $4.00 \pm 1.20$ & $3.92 \pm 1.25$ & 0.72 & $0.229^{\mathrm{NS}}$ \\
\hline 10. & $\begin{array}{l}\text { Rational appeal demonstrating } \\
\text { economy and savings in the purchase } \\
\text { of product. }\end{array}$ & $4.30 \pm 1.06$ & $4.05 \pm 1.22$ & 2.40 & $0.041^{*}$ \\
\hline
\end{tabular}

$N S=$ Non-Significant $;{ }^{*}$ Significant $(p<0.05) ;{ }^{* * *}$ Significant $(p<0.01)$.

In case of urban subjects higher score was given to fun and happiness with mean score of 4.28 followed by economy and saving (4.05), scenric beauty (3.92), music appeals (3.87), jungles and slogans (3.73), premium tie in (3.63), humor (3.61) and least importance was given to celebrity endorsement 
(3.45). The mean score of preference was found higher among rural children for majority of appeals and statistically significant difference in regard to importance was found with regard to celebrity endorsement $(\mathrm{p}=.009)$, Music appeals ( $\mathrm{p}=.008)$, Action/ Adventure and Thrilling Scenes ( $\mathrm{p}=.007)$, Humor $(\mathrm{p}=.008)$ and Economy and saving $(\mathrm{p}=.041)$. For all these appeals mean score of rural subject was higher except in case of humor were more weight age to this appeals was given by urban subjects. Overall, the results suggested that both subjects consider rational appeals like product performance featuring product attributes and educative information less important. Emotional appeals were considered more important for purchase decisions.

\subsection{Gender preferences for appeals}

Further analyses was done to investigate the gender differences with respect to importance given to appeals. Table 5 indicates that male subjects reported fun and happiness as most important emotional appeal for making purchase decision with the mean score 4.33 followed by economy and savings (4.30), music appeals (4.08), action and adventure and thrilling scene (3.86), humor (3.84), jingles and slogans (3.66) indicating that these appeals were considered important for them for making purchase decisions. Rational appeals like product performance and context and premium tie were given almost equal weightage with mean score of 3.53 and 3.54 respectively. However, emotional appeal of celebrity endorsement was rated very low with a mean score of 3.19 indicating that this appeal of social status was not so important for male children while making purchase decision. On the other hand, female subjects gave highest important to fun and happiness appeals with reported mean score of 4.37 followed by presence of scenic beauty (4.08), music appeals (4.06), economy and savings (4.05), celebrity endorsement (3.91) and jingles and slogans (3.90). Presence of action, adventure and thrilling scene, context and premium tie were given almost equal weightage i.e. mean score 3.63 and 3.62 respectively. Product performance featuring rational appeals were given lowest importance by female subject with a mean score 3.46 .

Table 5: Gender differences with respect to preferences for appeals in ads

\begin{tabular}{|c|l|c|c|c|c|}
\hline \multirow{2}{*}{$\begin{array}{c}\text { Sr. } \\
\text { No. }\end{array}$} & Promotional Appeal & Male & Female & $\begin{array}{c}\text { t- } \\
\text { value }\end{array}$ & $\begin{array}{c}\text { p- } \\
\text { value }\end{array}$ \\
\cline { 2 - 5 } 1. & $\begin{array}{l}\text { Mean } \pm \text { SD } \\
\text { Emotional Appeal depicting social } \\
\text { status like presence of celebrity in the } \\
\text { ads. }\end{array}$ & $3.19 \pm 1.41$ & $3.91 \pm 1.32$ & 5.78 & $0.004^{*}$ \\
\hline 2. & $\begin{array}{l}\text { Emotional Appeal like good music } \\
\text { for creation of mood and emotions }\end{array}$ & $4.08 \pm 1.11$ & $4.06 \pm 1.36$ & 0.18 & $0.917^{\mathrm{NS}}$ \\
\hline 3. & $\begin{array}{l}\text { Emotional appeal using catchy } \\
\text { phrases and words in form of jingles } \\
\text { and slogans }\end{array}$ & $3.66 \pm 1.25$ & $3.90 \pm 1.18$ & 2.16 & $0.045^{*}$ \\
\hline 4. & $\begin{array}{l}\text { Emotional appeal depicting use of } \\
\text { adventure/action and thrilling scene }\end{array}$ & $3.86 \pm 1.22$ & $3.63 \pm 1.46$ & 1.87 & $0.088^{\mathrm{NS}}$ \\
\hline 5. & $\begin{array}{l}\text { Rational appeal using } \\
\text { context/Premium tie in ads }\end{array}$ & $3.54 \pm 1.41$ & $3.62 \pm 1.28$ & 0.65 & $0.254^{\mathrm{NS}}$ \\
\hline 6. & $\begin{array}{l}\text { Rational appeal demonstrating } \\
\text { product use, benefits and products } \\
\text { features. }\end{array}$ & $3.53 \pm 1.34$ & $3.46 \pm 1.33$ & 0.57 & $0.289^{\mathrm{NS}}$ \\
\hline 7. & $\begin{array}{l}\text { Rational appeal depicting taste, } \\
\text { health and nutrients claims in the } \\
\text { product }\end{array}$ & $3.84 \pm 1.44$ & $3.79 \pm 1.36$ & 0.39 & $0.423^{\mathrm{NS}}$ \\
\hline 8. & $\begin{array}{l}\text { Emotional appeal demonstrating Fun } \\
\text { and Happiness to induce smiles and }\end{array}$ & $4.33 \pm 1.24$ & $4.37 \pm 1.12$ & 0.37 & $0.446^{\mathrm{NS}}$ \\
\hline
\end{tabular}




\begin{tabular}{|c|l|c|c|c|c|}
\hline 9. & laughter in the ads & & & & \\
\hline 9 & $\begin{array}{l}\text { Emotional appeal demonstrating } \\
\text { presence of striking scenes of nature } \\
\text { scenes, (Mountains, flowing streams } \\
\text { etc.) }\end{array}$ & $3.77 \pm 1.27$ & $4.08 \pm 1.19$ & 2.76 & $0.009^{* *}$ \\
\hline 10. & $\begin{array}{l}\text { Rational appeal demonstrating } \\
\text { Economy and Savings in the purchase } \\
\text { of product }\end{array}$ & $4.30 \pm 1.09$ & $4.05 \pm 1.23$ & 2.36 & $0.042^{*}$ \\
\hline
\end{tabular}

Computed from primary data, NS= Non-Significant $;{ }^{*}$ Significant $(p<0.05) ;{ }^{* * *}$ Significant $(p<0.01)$.

Statistically significant difference was found significant for social status appeals i.e. Celebrity endorsement $(\mathrm{p}=.004)$, jingles and slogan $(\mathrm{p}=.045)$, scenric beauty $(\mathrm{p}=.009)$. For all these emotional appeals female subject reported higher mean score than male subjects and in case of rational appeals significant difference was reported in one of the rational appeals i.e. economy and savings appeals $(\mathrm{p}=$ .042) where male subject reported higher mean score.

\subsection{Age -wise preferences for appeals}

Table 6 showed that fun $\&$ happiness was significantly important appeal considered by children of every age group. Moving towards individual age group, age group(8-10) reported that economy \& savings (4.27) stood next to fun \& happiness (4.41) in importance, followed by music (3.94), scenric beauty (3.84), jingles (3.77) and ending at product performance being least important (3.46), whereas, age group (10-12) too showed importance towards economy \& savings (4.33) after fun \& happiness (4.46) jointly followed by music (4.20) \& scenic beauty (4.19) further ensued by humor (3.98), action/ adventure (3.91) and closing at product performance (3.64), lastly, age group (12-14) found music for mood creation (4.06) important after fun \& happiness (4.19), after which economy \& savings (4.02), humor (3.90), scenic beauty (3.80) were considered important but at lower ranks, overall ending at product performance (3.36) being less appealing to children in this group. Moving to statistic, gap was found significant in humor $(f=$ 4.70), scenic beauty $(f=4.41)$ when tested at 99 percent of significance level and contest/ premium $(f=$ $3.30)$ and economy/ savings $(f=3.25)$ at 95 percent significance level.

\section{Conclusion}

The study indicated that all number of appeals present in food and beverages were large and the least were present in the case of toys and games. Emotional appeals like fun and happiness, jingles and slogans, humor was present in every commercial forming the base of appeals in commercials. The content of appeals like premium/content and parent pleasing in commercials was not found adequate. The result indicated that fun and happiness was most important emotional appeal in influencing the urban children purchase request as they enjoy looking at these ads and these ads create a remember able impact on their minds. Even the claims of health nutrient, taste flavor has a strong impact on the purchase decisions. Emotional appeal of action and adventure has a strong influence on their purchase request of rural children as many children as most of them reported during the survey reported that they bought Pepsi, complain, boast, glucon (D) just to get the same level of strength and energy as advertised. Their purchase request was strongly guided by the adventure of doing something exciting and different from others. Rational appeals like context, premiums were also reported to be very important. Many children reported that they bought Happy Meal of McDonald just to get the toy attach with that product. Once the advertising appeal having maximum likeability is determined, the advertisers would know the relative importance of these appeals in terms of perceptions of children. For all these emotional appeals female subject reported higher mean score than male subjects and in case of rational appeals significant difference was reported in one of the rational appeals i.e. economy and savings appeals where male subject reported higher preferences .Managers can then generate strategies that would be designed 
specifically for the target segments. Such differential strategies will help in enhancing the attractiveness and performance of advertising stimuli.

Research has shown that male and female children and teenagers seem to follow a different developmental path with respect to gender-stereotyped preferences. Boys tend to have greater resistance to opposite-sex activities than girls and tend to display increasing preferences for masculine activities throughout childhood. Girls, on the other hand, tend to move away from feminine preferences during middle childhood (Durkin, 1997). These differences between boys and girls might explain why traditional feminine appeals such as affection for animals and children, nurturing, and physical attractiveness hardly show up in commercials aimed at teenagers.

\section{REFERENCES}

1. Palan K, Rusell M, Laczniak L (1988). The relationship between advertising exposure and children's influence strategies while shopping. A conceptualized model. Iowa State University.

2. Wells W, Moriarty S, Burnett J. Advertising principles and practices $7^{\text {th }}$ edn. Pearson Prentice Hall, Upper Saddle River: 2006.

3. Derbaix, C. and Bree, J. (1997). The impact of children's affective reactions elicited by commercials on attitudes toward the advertisement and the brand. International Journal of Research in Marketing, 14, 207-229.

4. Moore, E. S. and Lutz, R. J. (2000). Children, advertising, and product experiences: A multimethod inquiry. Journal of Consumer Research, 27, 31-48.

5. Barcus, F. E. (1980). The nature of television advertising tot children. In E. L. Palmer and A. Dorr (Eds.), Children and the faces of television: Teaching, violence, selling (pp. 273-285). New York: Academic Press.

6. Kunkel D, Gantz W. (1992) Children's television advertising in the multichannel environment. Journal of Communication.; 42(4): 134-52.

7. Winick, C., Williamson, L. G., Chuzmir, S. F., and Winick, M. P. (1973). Children's television commercials: A content analysis. New York: Praeger.

8. Buijzen M, Valkenburg PM. Appeals in television advertising: A content analysis of commercials aimed at children and teenagers. Communication. 2002; 27(3): 349-64.

9. Neeley SM, Schumann RL. Using animated spokes-characters in advertising to young children. Journal of Advertising. 2004; 33(3): 7-23.

10. David Allan (2006) Effects of popular music in advertising on attention and memory. Journal of Advertising Research 2006, 434-44.

11. Robert, Pettigrew. Mothers' attitudes towards toys as fast food premiums. Young Consumers. 2006; 3: 60-7.

12. Page MR, Brewster A. Frequency of promotional strategies and attention elements in children's food commercials during children's programming blocks on US Broadcast Networks. Young Consumers. 2007; 18: 184-96.

13. Ganapatthy V. Power of Humor in Advertising. Advertising Express. 2009; 21-33.

14. Steve Dix et al. Bend it like Beckham: the influence of sports celebrities on young adult consumers. Young Consumers. 2010; 11(1): 36-46.

15. Boyland J. Emma et al. Persuasive techniques used in television advertisements to market foods to UK children. Appetite. 2011; (xxx-xxx). 